\title{
The Involvement of Women in Tourism Village of Pujon Kidul, Malang, Indonesia
}

\author{
Rita Parmawati*, Wike, Edriana Pangestuti \\ Postgraduate, University of Brawijaya, Malang, Indonesia
}

\begin{abstract}
Pujon Kidul Village has succeeded in tourism village, that improving the economy and social life and women's participation was seen in the technical sphere. It is interesting to analyze how women have played a role in a tourism village. This study aims to identify internal and external factors that support women's participation, identify the level participation, and analyze contributions to household income. We establish operational definitions in the form of internal and external factors and analyzed using cross tabulation and then Rank Spearman non-parametric statistical tests to provide an overview of study boundaries and data retrieval procedures. There are $56.7 \%$ of women who are graduating from high school/university and $173.33 \%$ have been in the tourism business for more than 5 years. Internal factors that have a significantly weak relationship are the level of women's education. Meanwhile, the aspect of the relationship between women's education level and women's participation as business actors in tourism villages was 100 percent in the low and medium categories, and 90 percent are in the high category. The influence of community actors to women participation is very high $(100 \%)$. There are $53.57 \%$ of women had a high level of participation and contribution to household income.
\end{abstract}

Keywords: Involvement, Pujon Kidul, Village tourism, Women.

\section{INTRODUCTION}

The role of women in the development of tourism has experienced considerable debate, mainly because it is sensitive to the political, economic, social and cultural context [1]. However, women become one of the promoters of entrepreneurship in tourism. In fact, their actions of participation and creativity are very different compared to men [2]. Women's involvement also initiates the growth of experience and challenges in business, relations, and increased financial access, resulting in increased quality of life [3].

The ratio of Indonesian population showed a larger number of women than men. But in reality, there is a gap in the level of work participation between both of them. The census in 2014 showed that the female labor force participation rate only reached $50.22 \%$, while the male reached $83.52 \%$ [4]. The lack of women's involvement is also seen in various strategic fields, for example, the parliament which only reached $17.32 \%$ and professionals who only reached $45.61 \%$. This will have an impact on household income contribution which only reaches $35.64 \%[5,6]$.

\footnotetext{
Correspondence address:

Rita Parmawati

Email : ritaparmawati1990@gmail.com

Address : Postgraduate School, University of Brawijaya, Mayjen Haryono No. 169, Malang, 65145.
}

However, we see that the role of women is considered very significant in rural development, one of which is through a tourism village program. This program was strongly initiated by the Ministry of Tourism through PNPM Mandiri Wisata, to increase the people's economic income, regional potential, and environmental sustainability [7]. In Pujon Kidul Village, Malang Regency, tourism village development has succeeded in improving the economy and social life of the community. The tour that was successfully built emphasized the role of regional arts and local products. However, full involvement of the community, especially women, is considered to be a separate force so that this tourism remains sustainable and growing.

In the case of tourism villages in Pujon Kidul, women's participation was seen in the technical sphere, such as culinary and souvenir activities, as well as inspirers and policymakers within the Tourism Awareness Group (POKDARWIS). This group is formed and managed independently for the sustainability of tourism villages. It is interesting to analyze how women have played a role in the development and management of a tourist village. The purpose of this study is to identify the internal and external factors that support women's participation in tourism village development. Internal and external factors are important for identifying the participation level of women's participation as entrepreneurs and 
analyze women's contributions to household income.

\section{MATERIAL AND METHOD}

The study was conducted in Pujon Kidul Village, Pujon District, Malang Regency in April 2017, which is one of the assisted villages of the local government in the development of the Tourism Village. This village is a pilot of the local government in a tourism village program and has even received a national award. Its development involves elements of the village community, both in the field of management and its workers, especially women. Therefore, this village is very suitable for research.

Respondents were determined by snowball techniques. We visited key figures to determine the respondents to be examined. We examined 30 respondents separately. This study used a quantitative and qualitative approach that is carried out together. In quantitative terms, questionnaires were used to understand the relationship of women's participation as business actors whose relationship as a participant, business actor, and their contribution to household income. Qualitatively, semi-structured in-depth interviews, observation, and field documentation were used.

The types of primary data obtained from the study were tested in tests of validity and reliability [8], then used in data analysis. The results of secondary data (documents and documentation) obtained were used to support the results of the analysis. Quantitative data results were presented in the frequency table, then processed with Microsoft Excel 2007 and IBM statistics 23.0. Then, a Spearman Rank correlation test was performed to show the level of significance or relationships between variables [8]. The form of relationship:

$$
\begin{array}{ll}
0.00-0.20 & =\text { Very weak } \\
0.21-0.40 & =\text { Weak } \\
0.41-0.70 & =\text { Strong } \\
0.71-0.90 & =\text { Very Strong } \\
0.91-0.99 & =\text { Very Much Strong } \\
1.00 & =\text { Perfect }
\end{array}
$$

We also establish operational definitions in the form of internal and external factors that induce women's involvement as businesses. This definition was formed to provide an overview of study boundaries and data retrieval procedures (Tables 1 and 2).

The correlation between internal and external factors of respondents with the participation of women as business actors in tourist villages was analyzed using cross-tabulation and then Rank Spearman non-parametric statistical tests were conducted to analyze the relationship between ordinal scale data and ordinal scale data. Decision making based on Sig. If the Sig. (2-tailed) or pvalue is smaller than the real level $(a)=0.05$, then $\mathrm{HO}$ is accepted, which means there is a significant relationship between the variables tested. The asterisk $\left(^{*}\right)$ in the correlation coefficient also shows the relationship between the variables tested. The nature of the correlation coefficient can be seen in data processing and analysis techniques. Internal factors of respondents consist of age, level of education, and length of women's business.

Tabel 1. Internal Factors that Influence Women

\begin{tabular}{|c|c|c|}
\hline Variables & Definitions & Indicators \\
\hline $\begin{array}{l}\text { Influence } \\
\text { Driving Actor } \\
\text { Participation }\end{array}$ & $\begin{array}{l}\text { Actor who } \\
\text { grows } \\
\text { Respondents' } \\
\text { participation in } \\
\text { tourism village } \\
\text { development }\end{array}$ & $\begin{array}{l}\text { 1.Low: influence of } \\
\text { private actors (banks, } \\
\text { insurers), value = } 1 \\
\text { 2.Medium: the } \\
\text { influence of motivating } \\
\text { actors from } \\
\text { government } \\
\text { institutions (regional / } \\
\text { central government), } \\
\text { value = } 2 \\
\text { 3.High: the influence of } \\
\text { the driving actor who } \\
\text { comes from the family } \\
\text { / community / tourism } \\
\text { conscious group, the } \\
\text { value = } 3 \\
\text { 1.Low: } 6-10 \\
\text { 2.Middle: } 11-15 \\
\text { 3.High: } 16-20\end{array}$ \\
\hline
\end{tabular}
Business Actors in Pujon Kidul Tourism Village

\begin{tabular}{lll}
\hline Variables & \multicolumn{1}{c}{ Definitions } & \multicolumn{1}{c}{ Indicators } \\
\hline Age & The length of life of & 1.Early (20-40 years) \\
& the respondent & 2.Middle (41-64 years) \\
& when the research & 3.Late (over 65 years) \\
& is conducted is & [9] \\
& calculated from the & \\
& date of birth stated & \\
& in the year & \\
\hline Level of & Educational stages & 1.Low: no schooling, \\
Education & are determined & not completed, \\
& based on the level & completed \\
& of development of & elementary school \\
& students. This level & 2.Middle: completed \\
& of education & junior high school \\
& consists of basic & 3. High: after senior \\
& education, & high school \\
& secondary & \\
& education and & \\
& higher education & \\
\hline Duration in & Duration of time a & 1.Low: $<2$ years \\
business & person spends to & 2.Middle : $2-5$ years \\
& do a work effort & 3.High: $>5$ years \\
\hline
\end{tabular}

Table 2. External factors that influence women business actors in the Pujon Kidul Tourism Village 


\begin{tabular}{|c|c|c|}
\hline Variables & Definitions & Indicators \\
\hline $\begin{array}{l}\text { Access Level } \\
\text { Women } \\
\text { Business } \\
\text { Actors in } \\
\text { Tourism } \\
\text { Villages }\end{array}$ & $\begin{array}{l}\text { There are } \\
\text { opportunities } \\
\text { for } \\
\text { respondent to } \\
\text { participate and } \\
\text { in the } \\
\text { development of } \\
\text { tourism villages }\end{array}$ & $\begin{array}{l}\text { There are } 5 \text { statement } \\
\text { items, each item has a } \\
\text { possible score: } \\
\text { Never }=1 \\
\text { Sometimes = } 2 \\
\text { Often = } 3 \\
\text { Always = } 4\end{array}$ \\
\hline $\begin{array}{l}\text { Fund Source } \\
\text { Level Business }\end{array}$ & $\begin{array}{l}\text { There are } \\
\text { opportunities } \\
\text { for } \\
\text { respondent to } \\
\text { participate } \\
\text { and in the } \\
\text { development of } \\
\text { tourism villages }\end{array}$ & $\begin{array}{l}\text { Based on field } \\
\text { observations, the level } \\
\text { of business funding } \\
\text { sources can be } \\
\text { classified into: } \\
\text { 1. Low: Source of funds } \\
\text { from the private sector } \\
\text { (bank, insurance), } \\
\text { value = 1 } \\
\text { 2. Medium: Source of } \\
\text { funds from } \\
\text { government } \\
\text { institutions (regional / } \\
\text { central government), } \\
\text { value = } 2 \\
3 . \text { High: Sources of } \\
\text { funds from family / } \\
\text { community / tourism } \\
\text { conscious groups, value } \\
=3\end{array}$ \\
\hline $\begin{array}{l}\text { Acceptance of } \\
\text { Patriarchal } \\
\text { Culture }\end{array}$ & $\begin{array}{l}\text { Cultural values } \\
\text { that place as } \\
\text { authority } \\
\text { holders in the } \\
\text { family, by giving } \\
\text { decisions to } \\
\text { women to } \\
\text { participate as } \\
\text { entrepreneurs in } \\
\text { the } \\
\text { development of } \\
\text { tourism villages }\end{array}$ & $\begin{array}{l}\text { 1.Low : } 1-5 \\
\text { 2.Middle : 6-10 } \\
\text { 3. High : } 11-15 \\
\text { There are } 3 \text { statement } \\
\text { items, each item has a } \\
\text { possible score: } \\
\text { Never }=1 \\
\text { Sometimes = } 2 \\
\text { Often = } 3 \\
\text { Always }=4\end{array}$ \\
\hline
\end{tabular}

\section{RESULT AND DISCUSSION}

\section{Internal Factors}

The results showed that as 12 women are in the age of young adults (Table 3 ). Thus women still have a lot of time and energy to carry out social activities outside the business of domestic activities. They are members of the community which are expected to be the main strength of the development of the Tourism Village. However, most of the respondents have reached middle-aged adults, where this factor will initiate women to mature family life, maintain social groups and economic life. Age variables have an impact on the quality of work and its relevance to work development innovations (Table 3). Workers who have a higher age, especially over 40 , have a lack of innovation and energy [10].

Based on age, there are $56.7 \%$ of women who are graduating from high school/university which describe the level of formal education as high. This strongly supports the involvement of women in Tourism Village Development. Education is the key to self and social maturity in initiating and finding innovation. Uniquely, $73.33 \%$ have been in business for more than 5 years. This illustrates the strength of women in entrepreneurship has been influential in the initiation of the formation of Tourism Villages, even before the arrival of government initiation. The results of the interviews revealed that their understanding of the potential of natural resources in their area was very good. The production results are used as raw materials for culinary business and sales of souvenirs that are now being undertaken. This illustrates that women have acted as part of a resilient and innovative rural community [11]. High education and the erosion of patriarchy culture make women freer to work and make decisions, including in the sale innovation of the products they created $[12,13]$.

Table 3. Number and Percentage of Respondents According to Age, Education Level and Length of Business in Pujon Kidul Tourism Village

\begin{tabular}{|c|c|c|}
\hline Internal Factors & Number (n) & $\begin{array}{c}\text { Percentage } \\
(\%)\end{array}$ \\
\hline \multicolumn{3}{|l|}{ Age } \\
\hline Early (20 - 40 years) & 12 & 40 \\
\hline Middle (41 - 64 years) & 18 & 60 \\
\hline Late (over 65 years) & 0 & 0 \\
\hline Total & 30 & 100 \\
\hline \multicolumn{3}{|l|}{ Level of Education } \\
\hline Low (not & 7 & 23,33 \\
\hline completed/completed & 6 & 20 \\
\hline primary school) & 17 & 56,67 \\
\hline \multicolumn{3}{|l|}{$\begin{array}{l}\text { Middle (completed junior } \\
\text { high school) }\end{array}$} \\
\hline \multicolumn{3}{|l|}{$\begin{array}{l}\text { High (completed senior high } \\
\text { school/college/university) }\end{array}$} \\
\hline Total & 30 & 100 \\
\hline \multicolumn{3}{|l|}{ Duration in business } \\
\hline Low (<2 years) & 0 & 0 \\
\hline Middle (2-5 years) & 8 & 26,67 \\
\hline Tinggi (>5 years) & 22 & 73,33 \\
\hline Total & 100 & 100 \\
\hline
\end{tabular}

The case of Pujon Kidul Tourism Village illustrated that women face increasingly severe challenges as internal factors. Even so, women have quite high participation (Table 4). The family economy must be fully supported by all its members, especially wives. Armed with education and experience about the village's natural resources, they become the initiators and active activists of the tourism village development groups. In Mersin, Turkey, women have acted as initiators in awakening the village's local economy and saving it from poverty through tourism development. This is done by the form of basic limitations and the desire to escape poverty [14]. 
The extent of women's experience is seen as effective to be the basis for the development of tourist villages. Most of the respondents have an effort that has been carried out intensely for more than 5 years. This role makes them more experienced in offering products and forms of tourism village management. Tourism destination management will be very important in strengthening competitiveness with other ]ourist destinations [15]. The form of management that deals directly with consumers is the quality of service. As a form of responsibility for the purpose of tourism, namely as a driver of economic, social, and environmental sustainability, the manager's role becomes very important. This is due to the fact that tourism formation is not temporary, but is sustainable and for a long time [16].

Correlation test results confirm previous findings. Internal factors that have a significantly weak relationship are the level of women's education (Table 5). This illustrated the form of participation that occurs not too affected by the level of education, but by the personal factors of the subject. The interview results illustrated the reason for this fact, where the willingness to change family conditions to a better economic level is a more important factor.

Another internal factor that has a strong negative relationship is the age level. Age affects physically in the maturity and will of women [16]. This is also illustrated by the distribution of respondents (Table 4). Meanwhile, the aspect of the relationship between women's education level and women's participation as business actors in tourism villages was 100 percent in the low and medium categories, and 90 percent are in the high category. These three categories have high participation. This is because the relationship between the level of education of women and their participation as business actors in tourism villages has a weak significance. This indicated that the level of education does not guarantee the level of participation as a business actor in a tourist village. Although women's education becomes something that is prioritized in society with the aim of developing themselves in the social activities of the community, participation with self-desires becomes more distinctive.

Furthermore, there was an interesting fact in the relationship between the length of business> 5 years with women's participation reaching $65.22 \%$, or in the high category and having high participation. This causes women who have long been doing business in the Pujon Kidul Tourism Village will know the environmental conditions and patterns of tourist visits, making it easier to adapt and carry out economic activities. In addition, the form of business that has been going on for a long time will be increasingly recognized and facilitate the marketing of its products. The high experience in managing business branding is very important for the business. Management of tourism areas is also no exception, where branding can improve competitiveness and construct various relationships with other economic businesses, such as travel, consumption, and investment [17].

Tabel 4. The Distribution of Respondents Based on the Correlation between Internal Factors and Women's Participation

\begin{tabular}{|c|c|c|c|c|c|c|c|c|c|}
\hline \multirow{2}{*}{\multicolumn{2}{|c|}{ Internal Factors }} & \multicolumn{8}{|c|}{ Women's Participation as Business Actors in the Tourism Village } \\
\hline & & \multicolumn{2}{|c|}{ Low } & \multicolumn{2}{|c|}{ Middle } & \multicolumn{2}{|c|}{ High } & \multicolumn{2}{|c|}{ Total } \\
\hline & & $\mathbf{n}$ & $\%$ & $\mathbf{n}$ & $\%$ & $\mathbf{n}$ & $\%$ & $\mathbf{N}$ & $\%$ \\
\hline \multirow[t]{3}{*}{ Age } & Low & 0 & 0 & 3 & 25 & 9 & 75 & 12 & 100 \\
\hline & Middle & 0 & 0 & 12 & 66.67 & 6 & 33.33 & 18 & 100 \\
\hline & High & 0 & 0 & 0 & 0 & 0 & 0 & 0 & 0 \\
\hline \multirow[t]{3}{*}{ Level of Education } & Low & 0 & 0 & 0 & 0 & 3 & 100 & 3 & 100 \\
\hline & Middle & 0 & 0 & 0 & 0 & 7 & 100 & 7 & 100 \\
\hline & High & 0 & 0 & 2 & 10 & 18 & 90 & 20 & 100 \\
\hline \multirow[t]{3}{*}{ Duration in business } & Low & 0 & 0 & 0 & 0 & 0 & 0 & 0 & 0 \\
\hline & Middle & 0 & 0 & 6 & 85.7 & 1 & 14.29 & 7 & 100 \\
\hline & High & 0 & 0 & 8 & 3.48 & 15 & 65.22 & 23 & 100 \\
\hline
\end{tabular}

Table 5. Rank Spearman Correlation Test between Internal Factors with Women's Participation as Business Actors.

\begin{tabular}{lc}
\hline \multicolumn{1}{c}{ Internal Factors } & Women's Participation as Business Actors in The Tourism Village \\
\hline Age & 0.025 ( $p$-value); $-0.408^{*}$ (correlation coefficient) \\
Level of Education & 0.039 ( $p$-value); $0.379^{*}$ (correlation coefficient) \\
Duration in business & 0.017 ( $p$-value); $0.432^{*}$ (correlation coefficient) \\
\hline
\end{tabular}




\section{External Factors \\ The level of influence of the actors who drive women's participation}

The influence of the actors driving the participation of women as entrepreneurs in tourism villages was reviewed through various involvement. The influence of participation activist actors was categorized into three groups, namely the influence of participation activists who come from the private sector, the government, and the community or tourism conscious groups. Based on the condition of the Pujon Kidul Tourism Village, which uses the concept of community-based tourism development (CBT), the highest policyholder of tourism village development is in the community. This has implications for the total utilization of the community towards village resources in the form of tourism village development, and each member can independently submit criticisms and suggestions for the development of the program. This is illustrated in Figure 1. The influence of society as an external factor occupies the highest portion compared to the government and the private sector.

The influence of community actors as drivers of women's participation in culinary business are very high (100\%), as well as the driving force of women's participation in souvenir business (83.33\%). Community actors who are families and members of the tourism awareness group described the spirit of community independence as the main capital in the formation of a tourist village. Community participation in initiating, working on and managing tourism villages is absolutely necessary to maintain sustainability [18].
Even though the numbers are not dominant, government actors influence women's participation. The government actors who are part of the industry and trade offices show that they are more dominant in driving souvenir business. The results of the interviews revealed that there was capital assistance channeled in small amounts, thus allowing participation.

\section{The level of women's access to tourism villages}

Women's access refers to something that can be achieved by women entrepreneurs in the development of tourism villages. This is the access of respondents to information on culinary and souvenir businesses, institutions, training information, providing criticism and suggestions, and access to monitoring tourism village development.

Access to information on culinary and souvenir businesses, as well as access to relative institutions are always conducted by respondents (Figure 2). This is because respondents want to get information on activities in tourist villages so that they can produce and market culinary or souvenir businesses for tourists who visit. Access to training information is relatively always carried out by respondents because respondents want to see new innovations that can be applied to their businesses. However, the respondent's access to monitoring village tourism development is quite often done. This is due to supervision activities carried out by tourism village managers and tourism conscious groups, despite the development of the Pujon Kidul Tourism Village using a community base.

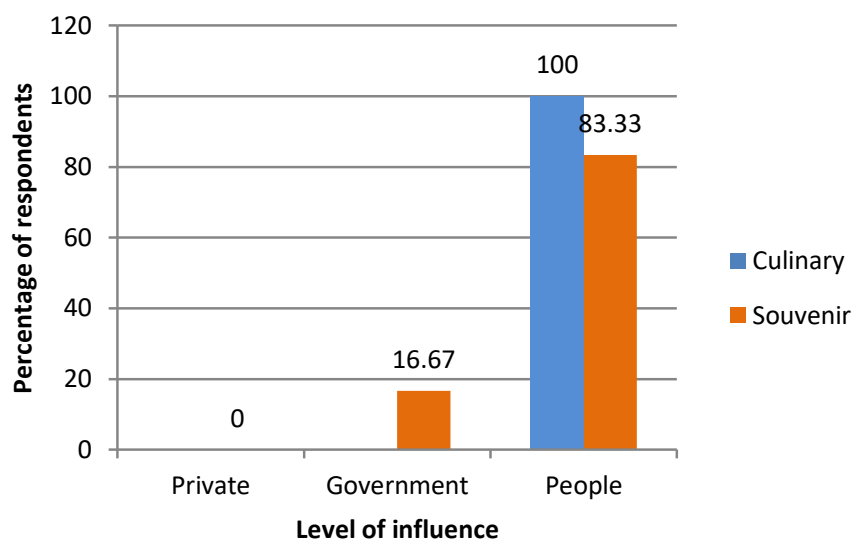

Figure 1. Percentage of respondents based on the level of influence of the driving actor of women's participation as culinary and souvenir entrepreneurs in the Pujon Kidul Tourism Village in 2018 


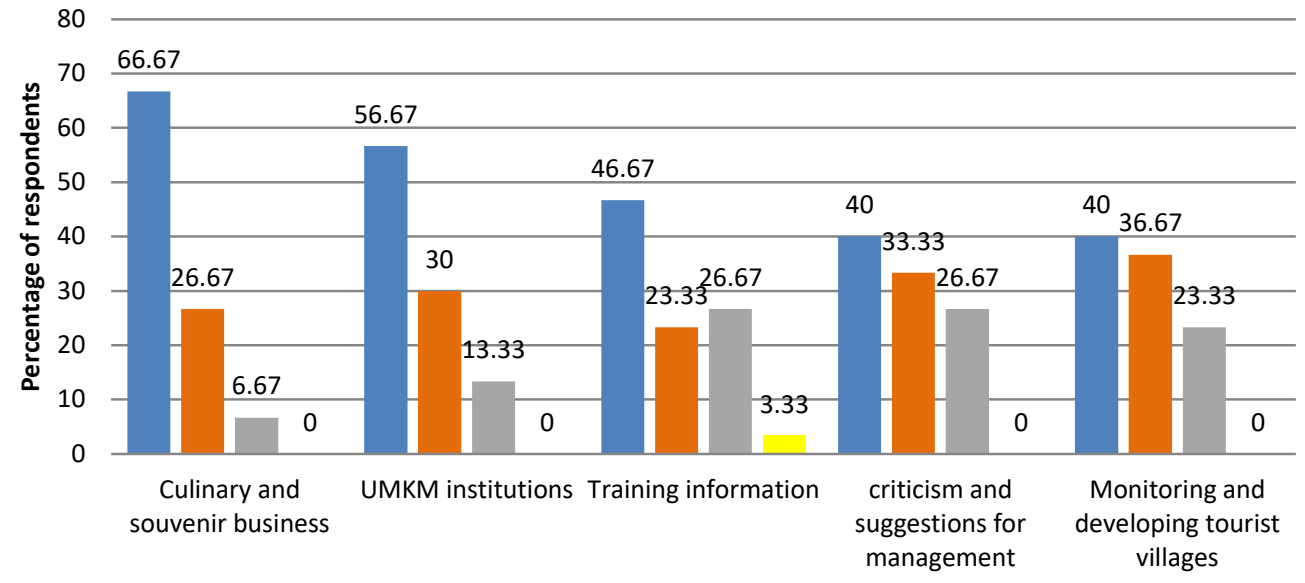

Level of Access of women enterpreneurs

always $\quad$ Often $\quad$ Seldom None

Figure 2. Percentage of respondents based on the level of access of women entrepreneurs in Pujon Kidul Tourism Village

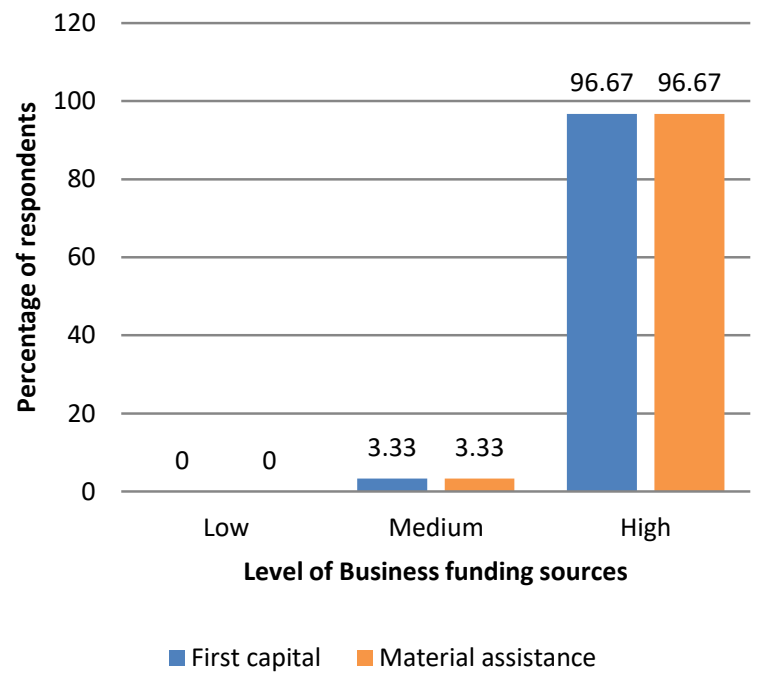

Figure 3. Percentage of respondents based on the level of business funding sources for women as entrepreneurs in Pujon Kidul Tourism Village in 2018

\section{The level of the source of business capital}

The level of the source of initial business capital for the participation of women entrepreneurs in the Pujon Kidul Tourism Village comes from the community $(96.67 \%$, Figure 3$)$. It is explained that the respondent began to start a business with personal or family finances, without applying for help from the private sector or the government. Observations showed that only 1 respondent received funding from the government. This is because the respondent submitted the proposal to the service (government) for the help of an oven machine so that the initial capital of the business in the form of an oven came from the government.
CBT once again provides a role for the Pujon Kidul Tourism Village so that the allocation of non-governmental funds is used for mutual benefit. The community was invited to negotiate together to achieve a common goal for the welfare of the Pujon Kidul Tourism Village community. This is supported by the results of research by Raharjana [19] which states that local residents are given absolute rights to participate in determining the future. Based on business funding sources from several sectors can be categorized into three categories. Figure 3 describes the percentage level of funding sources for women's participation as businesses in tourist villages. 


\section{The level of patriarchial culture acceptance}

Factors of Javanese culture that embrace many term patriarchal systems that position women lower than men both in the public sector and in the household. Patriarchal ideology characterizes that men are the household heads of breadwinners who are seen in productive work outside the home and as successors of descendants. However, the changing times have changed the role of women into benefits for families to increase income after marriage $[20,21]$. The permission of a husband or father as a business actor in the development of a tourist village, given criticism and suggestions by a husband or father as a business actor, and given material assistance by a husband or father as a relative business actor is always done by men to women in the Pujon Kidul Tourism Village.

Furthermore, women were relatively often given material assistance by husbands or fathers $(16.67 \%)$. This is caused by the turnover of the results of the business carried out by women reused as capital to buy raw materials. Overall respondents produce in the household so that they are often assisted by their husbands or fathers. If a production error occurs, the husband or father can reprimand and provide a solution.

Most women have a high level of acceptance of patriarchal culture (87\%). It shows that men are still positioned as the main (higher) than women. This is in line with the research of Nimrah and Sakaria [22] stating that most people assume that male domination still occurs in every field, as in families still dominated by men as well as in the workplace is still led by men.

Sihite [20] described the existence of a strong external factor in the form of cultural ideology adopted. Factors of Javanese culture that embrace a patriarchal system that positions women lower than men both in the public sector and in the household. In this study, most of the women have a high level of acceptance of patriarchal culture $(86.67 \%)$ proving that men have a higher position (position) than women, in their families and communities (Table 6).

Table 6. The number and percentage of respondents according to the level of acceptance of patriarchal culture women's participation as business people in the Pujon Kidul Tourism Village

\begin{tabular}{|c|c|c|c|c|c|c|c|c|}
\hline \multirow[t]{2}{*}{ The Acceptance of Patriachial Culture } & \multicolumn{2}{|c|}{ Always } & \multicolumn{2}{|c|}{ Often } & \multicolumn{2}{|c|}{ Seldom } & \multicolumn{2}{|c|}{ Never } \\
\hline & $\mathbf{n}$ & $\%$ & $\mathbf{n}$ & $\%$ & $\mathbf{n}$ & $\%$ & $\mathbf{n}$ & $\%$ \\
\hline $\begin{array}{l}\text { Get permission from the husband or father as a business actor in the } \\
\text { development of a tourist village }\end{array}$ & 29 & 96.67 & 1 & 3.33 & 0 & 0 & 0 & 0 \\
\hline Criticism and suggestions are given by husbands or fathers as business people & 26 & 86.67 & 3 & 10 & 1 & 3.33 & 0 & 0 \\
\hline Material assistance provided by husband or father as a business actor & 22 & 73.33 & 5 & 16.67 & 3 & 10 & 0 & 0 \\
\hline
\end{tabular}

\section{The Correlation between External factors and Women's Participation}

External factors that have a strong and significant relationship with women's participation are the level of influence of the actors driving participation, the level of access of women entrepreneurs in tourism villages, the level of business funding sources, and the level of acceptance of patriarchal culture.

The relationship between the influence of the motivating actors of women's participation and women's participation as business actors in tourism villages was $55.17 \%$ in the high category and had high participation. This is due to the willingness of the respondents to participate as entrepreneurs and develop the Pujon Kidul Tourism Village to be better and known by many people. Although there is one person who is driven by the government with assistance so that he can become a businessman in a tourist village.
Table 7. Correlation Test between External Factors with Women's Participation level as Business actors in Pujon Kidul Tourism Village

\begin{tabular}{lc}
\hline \multicolumn{1}{c}{ External Factors } & $\begin{array}{c}\text { Women's } \\
\text { Participation as } \\
\text { Business Actors }\end{array}$ \\
\hline Level of Driving Actors & 0.023 ( $p$-value); \\
Influence & $0.415^{*}$ \\
\hline Level of Women Acces as & 0.014 ( $p$-value); \\
Business Actors & $0.443^{*}$ \\
\hline Level of Source Capital & 0.023 (p-value); \\
& $0.415^{*}$ \\
\hline Level of Patriachal Culture & 0.013 (p-value); \\
Acceptance & $0.447^{*}$ \\
\hline
\end{tabular}

Furthermore, in Table 8 also shows the relationship between the levels of access of women entrepreneurs in tourism villages with the participation of women as entrepreneurs in tourism villages by 100 percent in the high category so that they have high participation. This is seen from access to information on 
business actors in tourist villages, access to the Mekarsari UMKM (Micro, Small, and Medium Enterprises, MSMEs) institution, access to training information, access to criticism and monitoring of tourism village management.

Meanwhile, the relationship between the level of business funding sources and the participation of women as business actors in tourism villages showed that the initial source of business funding came from themselves (family) and had high participation of $93.1 \%$. The majority of the initial business capital comes from the respondent's family. Women began to pursue culinary efforts with ingredients obtained around the tourist village, thereby reducing production costs. After successfully conducting production and marketing, respondents made large quantities of products to be marketed outside tourist villages. Meanwhile, the relationship between the level of acceptance of patriarchal culture and the participation of women as entrepreneurs in tourist villages in the Pujon Kidul Tourism Village shows that 96 percent have high participation in the acceptance of high patriarchal culture as well.
Patriarchal culture is still adhered to by respondents, it caused women to be able to do activities outside the home, such as attending training, marketing outside tourist villages, and nondomestic activities need to get permission from their husbands or fathers as holders of power in the household. In line with the results of Murdiyanto's research [23] which states that local communities are the part that best understands the state of the region, it will certainly be able to provide valuable input. The level of participation of women as business actors in tourist villages in the Pujon Kidul Tourism Village is in the high category of 53.33 percent. In the relationship of external factors with the participation of women as business actors in tourism villages, they managed to answer the hypothesis in this study. There is a strong significant relationship between the level of act of influence driving the participation of women, the level of access of women entrepreneurs in tourism villages, the level of business funding sources, and the level of acceptance of patriarchal culture with women's participation as entrepreneurs in tourist villages.

Table 8. Distribution of respondents according to the relationship between external factors and women's participation as business people in the Pujon Kidul Tourism Village

\begin{tabular}{|c|c|c|c|c|c|c|c|c|c|}
\hline \multirow{2}{*}{\multicolumn{2}{|c|}{ External Factors }} & \multicolumn{8}{|c|}{$\begin{array}{c}\text { Women's Participation as Business Actors in } \\
\text { The Tourism Village }\end{array}$} \\
\hline & & \multicolumn{2}{|c|}{ Low } & \multicolumn{2}{|c|}{ Middle } & \multicolumn{2}{|c|}{ High } & \multicolumn{2}{|c|}{ Total } \\
\hline & & $n$ & $\%$ & $n$ & $\%$ & $n$ & $\%$ & $\mathbf{N}$ & $\%$ \\
\hline Level of & Low & 0 & 0 & 0 & 0 & 0 & 0 & 0 & 0 \\
\hline Influence & Middle & 0 & 0 & 1 & 100 & 0 & 0 & 1 & 100 \\
\hline $\begin{array}{l}\text { of Driving } \\
\text { Actors }\end{array}$ & High & 0 & 0 & 13 & 44.83 & 16 & 55.17 & 29 & 100 \\
\hline Level of & Low & 0 & 0 & 0 & 0 & 0 & 0 & 0 & 0 \\
\hline \multirow[t]{2}{*}{ Acces } & Middle & 0 & 0 & 2 & 20 & 8 & 80 & 10 & 100 \\
\hline & High & 0 & 0 & 0 & 0 & 20 & 100 & 20 & 100 \\
\hline Level of & Low & 0 & 0 & 0 & 0 & 0 & 0 & 0 & 0 \\
\hline Capital & Middle & 0 & 0 & 0 & 0 & 1 & 100 & 1 & 100 \\
\hline Source & High & 0 & 0 & 2 & 6.9 & 27 & 93.1 & 29 & 100 \\
\hline Level of & Low & 0 & 0 & 0 & 0 & 0 & 0 & 0 & 0 \\
\hline Acceptance & Middle & 0 & 0 & 2 & 40 & 3 & 60 & 5 & 100 \\
\hline $\begin{array}{c}\text { of } \\
\text { Patriachal } \\
\text { Culture }\end{array}$ & High & 0 & 0 & 1 & 4 & 24 & 96 & 25 & 100 \\
\hline
\end{tabular}

Table 9. Number and percentage of respondents according to the level of women's participation as a businessman in the Pujon Kidul Tourism Village

\begin{tabular}{lcc}
\hline The degree of women's participation as business actors & Number $(\mathbf{n})$ & Percentage (\%) \\
\hline No Participation & 0 & 0 \\
Tokenism & 14 & 46.67 \\
Active Participation & 16 & 53.33 \\
& $\mathbf{3 0}$ & $\mathbf{1 0 0}$ \\
\hline
\end{tabular}


The level of women's participation as business actors

The participation category is measured by attendance at meetings and the delivery of aspirations in meetings classified as active participation with a total of 19 women (53.33\%, see Table 9). In addition, the participation category of women in tourism village development groups through Mekarsari MSMEs is categorized as tokenism or false participation (46.67\%).

The degree of female participation as a business actor in a tourist village can be seen in table 4.11 based on the accumulation of participation category questions that respondents answered from the answer choices 1-8 which represent the degree of participation. The degree of women's participation in the development of the Pujon Kidul Tourism Village is classified as active participation (53.33\%).

Participation in the development of Pujon Kidul Tourism Village also uses a community approach. There is high participation from citizens in decision making and implementation of actions [23]. Murdiyanto [24] which states that local communities become the part that best understands the state of the region will certainly be able to provide valuable input. Local people with their knowledge and experience become very large capital in carrying out development. It is the local community who knows what problems are faced and also the potential possessed by the region.

\section{Women's contribution to women's income as a business actors in a tourist village}

The income level consists of three categories, namely low income level $(<R p 3,796,596)$, medium income $(R p 3,796,596$ to $R p 16,433,268)$, and high (> Rp16,433,268) (Table 10). Women's income as entrepreneurs in tourist villages per month is in the low category of 66.67 percent. This is because the scope of marketing is still around tourist villages and food bazaar, only a portion of businesses are marketing to a broad market, such as marketing via the internet. Thus, the income of every woman doing business in the Pujon Kidul Tourism Village is different from one another. Basically, what generates direct income as a business actor in a tourist village is the sale of products marketed by women entrepreneurs when tourists visit.

\section{Women's contribution to houshold income}

Household income contributions are grouped into three categories based on average and standard deviation. The contribution of household income by women as entrepreneurs in tourism villages is relatively high $(53.37 \%$, see Table 9). The average husband's income and other income for the female household of business actors is Rp. 2,315,000. As much as 50 percent or part of women entrepreneurs in tourism villages, the level of contribution to household income is in the high category (> 49\%).

Relationship between the level of participation of women as business actors and the level of contribution to income

The results of this study indicated that women's participation as entrepreneurs in tourism villages has a strong significant relationship with their contribution to household income (Table 11). But in the table also mentioned the level of women's participation as business actors in tourism villages in the high category but its contribution to household income in the medium category was 32.14 percent. This is because, at the time of the interview, the results of the respondents' income were not as many as a few months ago due to the respondents not doing business production and marketing.

Table 10. Amount and percentage according to women's income level as perpetrators business in tourist villages in Pujon Kidul Tourism Village per month [4]

\begin{tabular}{lcc}
\hline The level of women's income as business actors & Number (n) & Percentage (\%) \\
\hline Low (<Rp3.796.596) & $\mathbf{2 0}$ & $\mathbf{6 6 . 6 7}$ \\
Middle (Rp3.796.596-Rp16.433.268) & 6 & 20 \\
High (>Rp16.433.268) & 4 & 13.33 \\
\hline Total & $\mathbf{3 0}$ & $\mathbf{1 0 0}$ \\
\hline
\end{tabular}

Table 11. Number and Percentage of women's contributrion to houshold income in Pujon Kidul per month

\begin{tabular}{lcc}
\hline Level of women's income as business actors & Number $(\mathbf{n})$ & Percentage (\%) \\
\hline Low $(<24 \%)$ & 5 & 16.67 \\
Middle $(24 \%-49 \%)$ & 10 & 33.33 \\
High $(>49 \%)$ & $\mathbf{1 5}$ & $\mathbf{5 0}$ \\
\hline Total & $\mathbf{3 0}$ & $\mathbf{1 0 0}$ \\
\hline
\end{tabular}


Table 12 The number and percentage of respondents according to their level of participation as businesses in tourist villages

\begin{tabular}{lcccccccc}
\hline & \multicolumn{4}{c}{ Level of contribution to houshold income } \\
\cline { 2 - 10 } The level of women's participation as business actors & \multicolumn{2}{c}{ Low } & \multicolumn{2}{c}{ Middle } & \multicolumn{3}{c}{ High } & \multicolumn{2}{c}{ Total } \\
& $\mathbf{n}$ & $\%$ & $\mathbf{n}$ & $\mathbf{\%}$ & $\mathbf{n}$ & $\mathbf{\%}$ & $\mathbf{N}$ & $\%$ \\
\hline Low & 0 & 0 & 0 & 0 & 0 & 0 & 0 & 0 \\
Middle & 1 & 50 & $\mathbf{1}$ & $\mathbf{5 0}$ & 0 & 0 & 2 & 100 \\
High & 4 & 14.29 & 9 & 32.14 & $\mathbf{1 5}$ & $\mathbf{5 3 . 5 7}$ & $\mathbf{2 8}$ & 100 \\
\hline Total & $\mathbf{5}$ & $\mathbf{1 6 . 6 7}$ & $\mathbf{1 0}$ & $\mathbf{3 3 . 3 3}$ & $\mathbf{1 5}$ & $\mathbf{5 0}$ & $\mathbf{3 0}$ & $\mathbf{1 0 0}$ \\
\hline
\end{tabular}

In addition, the results of this study found that 53.57 \%of women had a high level of participation and the level of contribution to household income was high. So it can be said that women have a large role in supporting the family economy in addition to income from the husband. The results of previous studies show that along with the times, the role of women as housekeepers working in the domestic sector has experienced a shift. At present women do not only work in the domestic sector but also as main and additional breadwinners [25].

Women's participation as entrepreneurs in tourism villages has a significant relationship with their contribution to household income. As much as 66.67 percent of women's income as businesses in tourist villages per month is in the low category (<Rp. 3,796,596 per month, see Table 10). This is because, at the time of the interview, the results of the respondents' income were not as many as a few months ago due to the respondents not doing business production and marketing. But the level of contribution to household income is in the high category by $53.57 \%$ (Table 12).

This illustrates that the higher of participation of women as business people, the higher their contribution to household income. The results of previous studies also support these findings, which along with the times, the role of women as housekeepers working in the domestic sector has undergone a shift. Now, women not only work as additional income but also as the main and additional breadwinners [26].

\section{CONCLUSION}

We uncover internal factors that influence women's participation: the character of women as business actors, age, education and business period. Age has a negative influence on the development of tourism villages. While the external influencing factors consist of the emergence of business activists, initial capital, and patriotic culture. In general, the level of participation of women in tourism villages is quite high (53.33\%), and is classified as active participation. Women's contribution to culinary and souvenir businesses for family income reached $53.37 \%$

\section{REFERENCES}

[1] Dumbrăveanu, D., D. Light, C. Young and A. Chapman. 2016. Exploring women's employmenet in tourism under statesocialism: experiences of tourism work in socialist Romania. Tourist Studies 16(2), 151-169.

[2] Serafimova, M. and B. Petrevska. 2018. Female entrepreneurship in tourism: A Strategic Management Perspective in Macedonia. Journal of Applied Economic and Business 6(1), 21-32.

[3] Deen, A., V. Harilal, and F. N. Achu. 2016. Women in Toursim: expereiences and challenges faced by owners of small accommodation establisments. African Journal of Hospitality, Tourism and Leisure 5(3), 1-15.

[4] Statistic Center. 2017. Tingkat partisipasi angkatan kerja (TPAK) Jawa Timur. Available at: https://jatim.bps.go.id/dynamictable/ 2017/11/16/145/tingkat-partisipasiangkatan-kerja-tpak-menurut-kabupatenkota-2001-2017.html.

[5] Dewi, P. M. 2012. Partisipasi tenaga kerja perempuan dalam meningkatkan pendapatan keluarga. Jurnal Ekonomi Kuantitatif Terapan 5(2), 119-124.

[6] Syahputri, E. 2014. Keterwakilan perempuan di parlemen: komparasi Indonesia dan Korea Selatan. Indonesian Journal of Internatioal Studies 1(2), 165176. 
[7] TPWDK (Team for accelerating rural and urban tourism development). 2017. Pengembangan Desa Wisata. Kemenpar. Available at: http://kemenpar.go.id.

[8] Effendi S, Tukiran. 2012. Metode Penelitian Survei. LP3ES. Jakarta.

[9] Nugroho, B. A. 2005. Strategi Jitu Memilih Metode Statistik Penelitian dengan SPSS. Andi Press. Yogyakarta.

[10] Santrock, J. W. 2002. Life-Span Development (Perkembangan Masa Hidup), $1^{\text {st }}$ Ed. Erlangga. Jakarta.

[11] Kumbadewi, L. S., I. W. Suwendra, G. P. A. J. Susila. 2016. Pengaruh umur, pengalaman kerja, upah, teknologi dan lingkungan kerja terhadap produktivitas karyawan. E-journal Bisma Universitas Pendidikan Ganesha $4(1), 1-11$

[12] UNWTO. 2010. Global report on women in tourism. Preliminary findings. UN Women.

[13] Ovsenik, M. 2013. Challenges for tomorrow tourism education - the case of slovenia. Informatol 46(2), 99-110.

[14] Perman, L. and K. Mikinac. 2014. Effectiveness of education processes in tourism and hospitality in the republic of Croatia. Congress Procedings of Trends in Tourism and Hospitality Industry. 616-630.

[15] Rad, S. T. 2011. An application of a womenoriented agro-tourism rural development model in improving local economy. African Journal of Business Management 5(22), 9714-9723.

[16] Bosnić, I., J. Stanišić, and D. Tubić. 2014. Role of destination management in strengthening the competitiveness of croatian tourism. Journal of Contemporary Management Issues 17(1), 153-170.

[17] Sandaruwani, J. A., R. I. Chehanika and W.K.A. Gnanapala. 2016. The role of tourist guides and their impacts on sustainable tourism development : a critique on sri lanka. Tourism, leisure, and global change 3, TOC-63.

[18] Manhas, P. S., L. A. Manrai, and A. K. Manrai. 2016. Role of tourist destination development in building its brand image: $A$ conceptual model. Journal of Economics, Finance and Administrative Science 21, 2529.

[19] Permanasari I. 2010. Pengentasan kemiskinan melalui pemberdayaan masyarakat di desa wisata. Jurnal Kepariwisataan Indonesia 5(1), 57-69.
[20] Raharjana, D. T. 2012. Membangun pariwisata bersama rakyat: kajian partisipasi local dalam membangun desa wisata di Dieng Plateau. Kawistara 2(3), 225-328.

[21] Sihite, R. 2007. Perempuan, kesetaraan, dan keadilan "suatu tujuan berwawasan gender". PT Raja Grafindo Persada. Jakarta.

[22] Ogletree, S. M. 2014. Gender role attitudes and expectations for marriage. Journal of research on Women and Gender 5, 71-82.

[23] Nimrah, S. S. 2015. Perempuan dan budaya patriarki dalam politik: studi kasus kegagalan caleg perempuan dalam pemilu legislative 2014. The POLITICS : Jurnal Magister Ilmu Politik Universitas Hassanudin 1(2), 173-182.

[24] Murdiyanto, E. 2011. Partisipasi masyarakat dalam pengembangan Desa Wisata Karanggeneng, Purwobinangun, Pakem, Sleman. Jurnal Sosial Ekonomi Pertanian dan Agribisnis (SEPA) 7(2), 91-101.

[25] Nasdian, F. T. 2014. Pengembangan masyarakat. Yayasan Obor Indonesia. Jakarta.

[26] Sayogyo, P. 1981. Peranan wanita dalam pembangunan di berbagai lingkungan, desa dan kota: suatu tinjauan sosiologi. Faculty of Agriculture, Bogor Agricultural University. Bogor. 